\title{
STUDI DINAMIKA SENYAWA FOSFAT DALAM KUALITAS AIR SUNGAI CILIWUNG HULU KOTA BOGOR
}

\author{
RTM Sutamihardja ${ }^{1)}$, Mia Azizah ${ }^{2)}$, Yunita Hardini ${ }^{1 *}$ \\ ${ }^{1)}$ Program Studi Kimia FMIPA Universitas Nusa Bangsa Bogor \\ ${ }^{2)}$ Program Studi Biologi FMIPA Universitas Nusa Bangsa Bogor \\ Jl. KH Sholeh Iskandar KM 4 Cimanggu Tanah Sareal, Bogor 16166 \\ *email : yh.dini165@gmail.com
}

\section{ABSTRACT \\ Study of Dynamics of Phosphate in the Water Quality in Bogor of Upstream Ciliwung River}

\begin{abstract}
Ciliwung River has existed and become an important part of the community since ancient period. Since 2009, the Ciliwung River has been polluted condition from upstream. One of the pollutant that could decrease the quality of river water was phosphate. Excessive phosphate level in water bodies caused nutrient enrichment conditions (eutrophication). The presence of nitrate supporting phosphate also caused algae blooming, one of the environmental problem. The research was conducted to determine the dynamics of the phosphate compound of Ciliwung River whether the pollution was reduced, same, or worse. The research included sampling of river water at three points of Katulampa, Pasar Bogor, and Warung Jambu River with sampling time interval of 8 hours in a day for 3 weeks in a row. The data of phosphate and nitrate concentration were measured and compared to the results in PP No.82 year 2001. The total of phosphate in Ciliwung river water has exceeded threshold level in accordance with the environmental quality standard of PP. 82 year 2001, and has been indicated to be in eutrophication condition.
\end{abstract}

Keywords: Ciliwung River, Water Quality, Water Pollution, Phosphate.

\begin{abstract}
ABSTRAK
Sungai Ciliwung telah ada dan menjadi bagian penting masyarakat sejak zaman purba. Namun seiring dengan berlalunya waktu dan perkembangan pesat, sejak tahun 2009 Sungai Ciliwung telah tercemar dari hulu. Salah satu polutan yang bisa menurunkan kualitas air sungai adalah fosfat. Keberadaan fosfat yang berlebihan di badan air dapat menyebabkan kondisi pengayaan nutrisi (eutrofikasi), dan dengan dukungan nitrat dapat menyebabkan algae blooming yang menjadi salah satu masalah lingkungan. Penelitian ini dilakukan untuk mengetahui dinamika senyawa fosfat Sungai Ciliwung apakah pencemarannya berkurang, sama, atau lebih buruk. Ruang lingkup penelitian meliputi pengambilan sampel air sungai pada tiga titik Katulampa, Pasar Bogor, dan Warung Jambu dengan interval waktu sampling 8 jam dalam sehari, dan dilakukan setiap minggu selama 3 minggu berturut-turut. Kemudian dilakukan analisis sampel di laboratorium, serta interpretasi data dengan membandingkan hasilnya terhadap PP No.82 tahun 2001. Nilai total fosfat di air sungai Ciliwung Hulu tidak memenuhi standar kualitas lingkungan PP. 82 tahun 2001, dan diindikasikan berada dalam kondisi eutrofikasi.
\end{abstract}

Kata kunci: Sungai Ciliwung, Kualitas Air, Polusi Air, Fosfat.

\section{PENDAHULUAN}

Sungai Ciliwung merupakan salah satu sungai penting di Jawa Barat. Sungai Ciliwung secara geografis terletak di daerah yang dibatasi antara $6^{\circ} 05^{\prime}-6^{\circ} 50^{\prime}$ LS dan $106^{\circ} 40^{\prime}-107^{\circ} 0^{\prime}$ BT. Daerah Aliran Sungai (DAS) Ciliwung memiliki luas areal 347 $\mathrm{km}^{2}$, dan panjang $117 \mathrm{~km}$. Sungai ini memiliki peran penting dalam mendukung aktivitas manusia yang ada di sekitarnya (Priyono, 2011).
Bertambahnya jumlah penduduk dan meningkatnya aktivitas masyarakat di bagian hulu, disinyalir menjadi penyebab utama terjadinya kerusakan lingkungan. Sumber pencemaran di DAS Ciliwung berasal dari limbah domestik/rumah tangga berupa sampah dan limbah cair rumah tangga, limbah dari kegiatan peternakan, limbah pertanian dari pemakaian pupuk dan pestisida yang berlebihan, serta limbah buangan dari industri kecil (Manurung, 2014). 
Menurut Ndani (2016) salah satu bahan pencemar yang dapat menurunkan kualitas air sungai adalah fosfat. Keberadaan fosfat yang berlebihan pada badan air dapat menyebabkan kondisi penyuburan unsur hara perairan (eutrofikasi). Menurut Effendi (2003) suatu perairan dikatakan eutrofik jika konsentrasi total fosfat berada dalam rentang konsentrasi 35-100 $\mu \mathrm{g} / \mathrm{L}$. Eutrofikasi merupakan sebuah proses alamiah di mana perairan mengalami penuaan secara bertahap dan menjadi lebih produktif bagi tumbuhnya biomassa. Kondisi eutrofik memerlukan proses ribuan tahun. Namun proses alamiah ini, oleh manusia dengan segala aktivitas modernnya, secara tidak disadari dipercepat menjadi dalam hitungan beberapa dekade atau bahkan beberapa tahun saja. Kondisi eutrofik perairan dapat memicu terjadinya fenomena blooming algae (ledakan populasi fitoplankton), yaitu pada kondisi perairan yang tenang dan tidak mengalir seperti di danau, kolam, dan laut. Hasil pemantauan BPLH Kota Bogor (BPLHD, 2014) dan hasil penelitian Khoerussani (2014) menunjukkan nilai fosfat mengalami fluktuasi dan tidak memenuhi baku mutu kelas I dan II, sehingga air sungai Ciliwung tidak dapat digunakan sebagai air baku untuk air minum, tetapi dapat digunakan untuk sarana rekreasi air, pembudidayaan ikan, peternakan, dan untuk pengairan tanaman. Kota Bogor pada tahun 2017.

Tujuan dari penelitian ini adalah untuk mengetahui fluktuasi senyawa fosfat pada kualitas air Sungai Ciliwung bagian hulu di segmen Kota Bogor tahun 2017 berdasarkan baku mutu Peraturan Pemerintah No. 82 tahun 2001.

\section{BAHAN DAN METODE}

\section{Bahan dan Alat}

Bahan yang digunakan antara lain asam sulfat $5 \mathrm{~N}$, kalium antimonil tartrat, amonium molibdat, asam askorbat (pereaksi campuran), larutan asam sulfat $1: 1, \mathrm{NaOH}$ $10 \mathrm{~N}$, amonium persulfat, larutan induk fosfat, Glass Fibre Filter (Whatman 934$\mathrm{AH}$ atau yang sejenis), larutan buffer fosfat, larutan magnesium sulfat, larutan kalsium klorida, larutan ferri klorida, larutan SEED, dan larutan standar Glucose/Glutamic Acid, larutan standar nitrat, larutan amonium klorida-EDTA, kolom pereduksi $\mathrm{Cu}-\mathrm{Cd}$, glass wool.

Alat yang digunakan antara lain: spektrofotometer UV-Vis, DO-meter, konduktometer, $\mathrm{pH}$-meter, pinset, desikator, alat penyaring, cawan aluminium, botol BOD, inkubator, neraca analitik, piala gelas, spatula, oven, labu semprot, labu takar, kolom reduksi, dan digestion block.

\section{Metode}

\section{Pengambilan sampel}

Lokasi pengambilan sampel dilakukan di 3 titik yaitu bendung Katulampa, Pasar Bogor, dan Warung Jambu pada waktu pagi, siang, dan malam hari berdasarkan SNI 037016-2004, menggunakan metode Grab (Sesaat). Sampel diambil secara horizontal (kiri, tengah, dan kanan) masing-masing sebanyak 1 liter, lalu dikomposit, displit, dan dilakukan pengawetan sampel untuk parameter Fosfat dan Nitrat dan dianalisis di laboratorium. Parameter Total Suspended Solid (TSS) tanpa diawetkan, dan parameter $\mathrm{pH}$, suhu, DO dilakukan di lapangan.

\section{Analisis Total-Fosfat Berdasarkan APHA Method 4500-P A,B,E (APHA, 2005)}

Sampel sebanyak $15 \mathrm{~mL}$ dikocok, dituangkan ke dalam tabung reaksi, lalu ditambahkan $0,2 \mathrm{~mL}$ asam sulfat dan 0,1 gram amonium persulfat, dipanaskan pada suhu $100^{\circ} \mathrm{C}$ selama $1 / 2$ jam, kemudian angkat dan ditambahkan 2,4 mL pereaksi campuran, lalu diaduk dan ditunggu 10 menit, didinginkan, dan ditambahkan indikator PP beberapa tetes dan $\mathrm{NaOH} 10 \mathrm{~N}$ sampai warna larutan menjadi merah muda. Kemudian diukur absorbansinya menggunakan spektrofotometer UV-Vis pada panjang gelombang $880 \mathrm{~nm}$.

\section{Analisis TSS Berdasarkan APHA Method 2540-D (APHA, 2005) \\ Fiber glass filter (kertas saring) ditempatkan di cawan, dikeringkan dalam oven $105^{\circ} \mathrm{C} 1 \mathrm{jam}$, lalu didinginkan di dalam}


desikator, dan ditimbang bobot kosongnya. Sampel sebanyak $25 \mathrm{~mL}$ disaring, lalu dipanaskan pada suhu $105^{\circ} \mathrm{C}$ selama 1 jam. Cawan didinginkan di desikator lalu ditimbang sebagai bobot isi.

\section{Analisis BOD Berdasarkan APHA Method 5210-B (APHA, 2005)}

Sampel diencerkan, lalu ditambahkan larutan pengencer ke dalam botol BOD., dicatat nilai $\mathrm{DO}_{0}$ dalam blanko dan sampel hasil pengenceran, botol BOD ditutup sehingga tidak ada lagi gelembung udara, dan tertutup dengan air (water seal), ditutup bagian atas botol dengan parafilm dan diinkubasi selama 5 hari pada suhu tetap $\left(20^{\circ} \mathrm{C}\right)$ di ruang gelap. Setelah 5 hari inkubasi nilai DO dalam blanko dan sampel yang diencerkan diukur kembali kemudian dicatat sebagai $\mathrm{DO}_{5}$.

\section{Analisis Nitrat berdasarkan APHA Method 4500-NO $\mathrm{N}_{3}$-E (APHA, 2005)}

Sampel sebanyak $25 \mathrm{~mL}$ diencerkan dengan larutan ammonium-EDTA hingga $100 \mathrm{~mL}$. Larutan tersebut kemudian dilewatkan ke kolom $\mathrm{Cu}-\mathrm{Cd}$ untuk direduksi menjadi nitrit dengan kecepatan aliran 7-10 mL/menit. Hasil reduksi sebanyak $25 \mathrm{~mL}$ dimasukkan ke dalam labu takar, lalu ditambahkan $1 \mathrm{~mL}$ larutan pereaksi warna buffer dimasukkan ke dalam sampel tersebut dan dikocok sebentar, didiamkan 10 menit, diukur absorbansinya pada panjang gelombang $540 \mathrm{~nm}$.

\section{HASIL DAN PEMBAHASAN}

\section{A. Parameter Penunjang}

Berdasarkan hasil analisis pada setiap lokasi pengambilan sampel, dapat dilihat pengaruh parameter penunjang (faktor lingkungan) terhadap fosfat. Parameter penunjang tersebut diantaranya adalah :

\section{Suhu}

Nilai rata-rata suhu (Gambar 1) dari titik Katulampa, Pasar Bogor, dan Warung Jambu mengalami peningkatan, nilai suhu berkisar antara $25,5^{\circ} \mathrm{C}-26,0^{\circ} \mathrm{C}$. Suhu air yang meningkat dapat menyebabkan metabolisme dan respirasi organisme air meningkat, sehingga cenderung menambah kekeruhan. Hal tersebut dapat diakibatkan adanya akumulasi limbah ke dalam badan sungai (Tungka, Haeruddin, dan Ain, 2016). Limbah yang masuk ke dalam sungai akan diuraikan oleh bakteri dari bentuk makromolekul menjadi mikromolekul (katabolisme), sehingga menghasilkan energi berupa kalori. Semakin banyak energi yang dihasilkan akan menyebabkan suhu air semakin tinggi (Effendi, 2003).

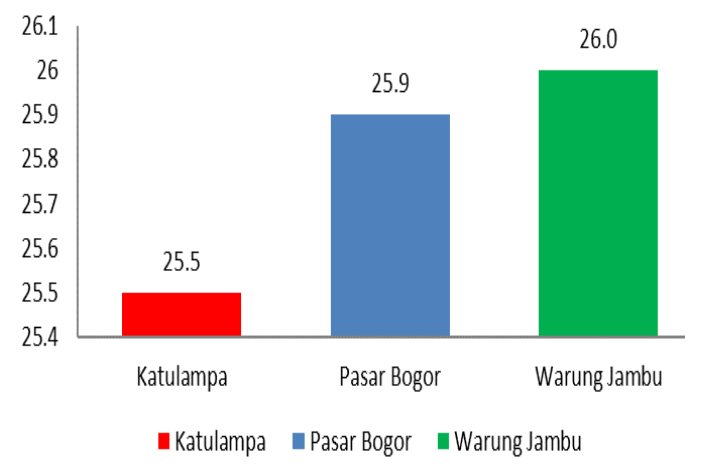

Gambar 1. Nilai Suhu Rata-Rata 2017

\section{2. $\mathbf{p H}$}

Nilai rata-rata $\mathrm{pH}$ dari titik Katulampa, Pasar Bogor, sampai Warung Jambu mengalami penurunan, nilai $\mathrm{pH}$ berkisar antara 7,0-7,3 (Gambar 2). Limbah yang dibuang tidak bersifat asam atau basa dalam kadar yang tinggi, namun lebih bersifat organik yang dapat terurai baik secara biologis maupun kimiawi (Wardhana, 2004).

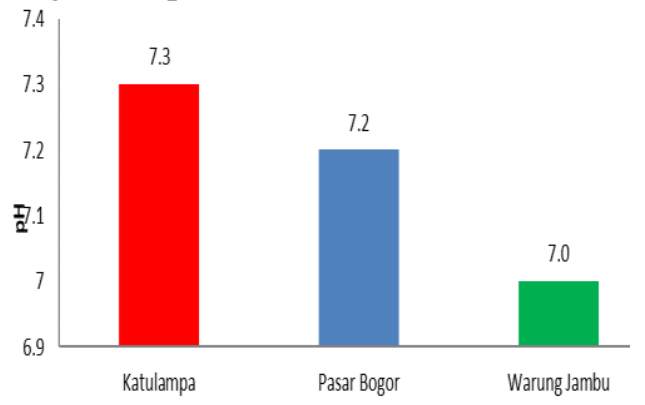

Gambar 2. Nilai pH Rata-Rata 2017

\section{Oksigen Terlarut (Dissolved Oxygen/DO)}

Nilai rata-rata DO dari titik Katulampa, Pasar Bogor, sampai Warung Jambu mengalami penurunan, nilai DO berkisar antara 6,0-6,4 mg/L (Gambar 3). Menurut Tungka et al., (2016) semakin 
rendahnya kadar oksigen terlarut berkaitan dengan peningkatan aktivitas mikroorganisme dalam menguraikan zat organik yang menggunakan oksigen terlarut.

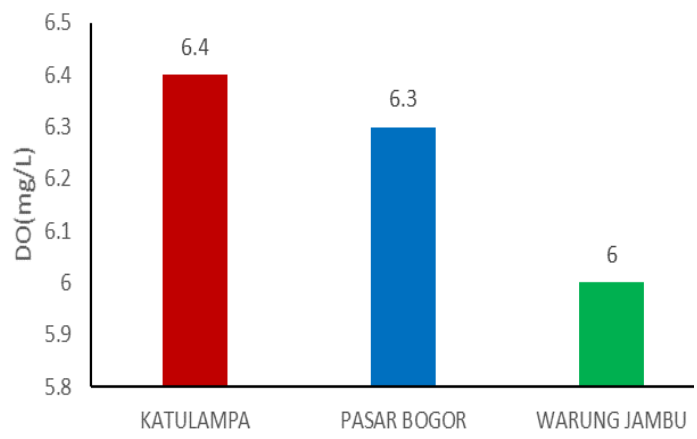

Gambar 3. Nilai DO Rata-Rata 2017

\section{Total Padatan Tersuspensi (Total Suspended Solid/TSS)}

Nilai rata-rata TSS dari titik Katulampa, Pasar Bogor, hingga Warung Jambu mengalami peningkatan, nilai TSS berkisar antara 24-29 mg/L (Gambar 4). Hal ini disebabkan oleh akumulasi material padatan tersuspensi dari partikel-partikel bahan organik, anorganik, mikroorganisme, buangan limbah domestik, limbah pertanian, limbah industri, dan peternakan ayam di sekitar daerah aliran sungai. Menurut Kusuardini (2011), nilai TSS yang tinggi berakibat pada terhalangnya penetrasi sinar matahari ke dasar sungai, sehingga proses fotosintesis perairan terganggu.

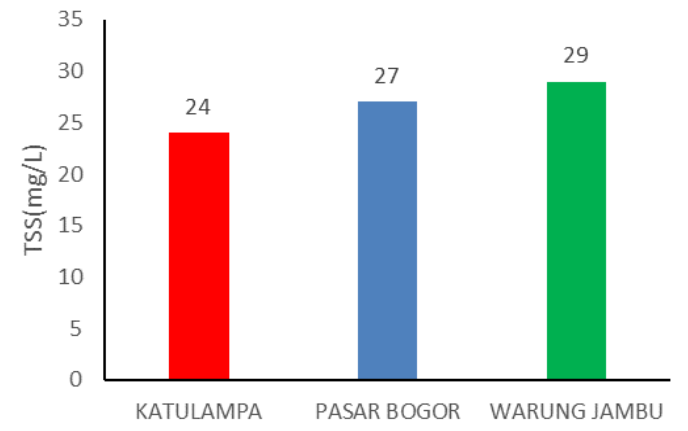

Gambar 4. Nilai TSS Rata-Rata 2017

\section{Kebutuhan Oksigen Biologis (Biologycal Oxygen Demand/BOD)}

Nilai rata-rata BOD dari titik Katulampa, Pasar Bogor, hingga Warung Jambu mengalami peningkatan, nilai BOD berkisar antara 11-14 mg/L (Gambar 5). Hal ini disebabkan oleh akumulasi limbah domestik, limbah aktivitas pasar, limbah buangan industri serta peternakan ayam yang berada di sepanjang DAS. Pada siang hari nilai BOD lebih tinggi, karena pada proses fotosintesis fitoplankton menghasilkan oksigen yang cukup untuk proses penguraian bahan organik (Trofisa, 2011).

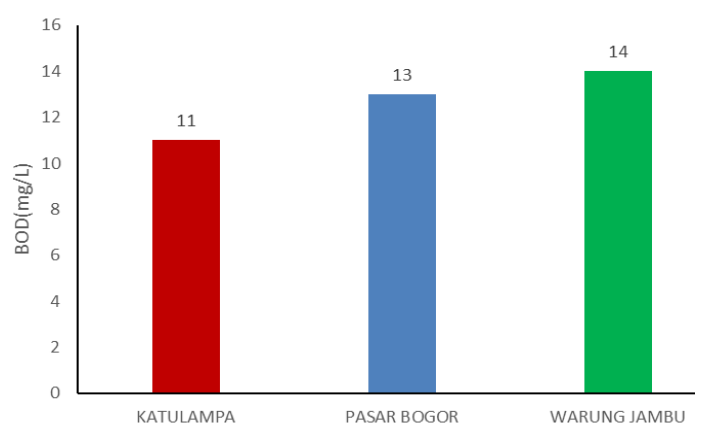

Gambar 5. Nilai BOD Rata-Rata 2017

\section{Nitrat}

Nilai rata-rata nitrat dari titik Katulampa, Pasar Bogor, hingga Warung Jambu mengalami peningkatan, nilai nitrat berkisar antara 0,764-0,807 mg/L (Gambar 6). Hal ini disebabkan oleh akumulasi buangan limbah rumah tangga, sekresi urin, dan penggunaan pupuk di sepanjang aliran sungai. Peningkatan nilai nitrat terjadi pada siang hari, dikarenakan fitoplankton memanfaatkan nitrat sebagai sumber makanan (zat hara) dengan bantuan sinar matahari di siang hari pada proses fotosintesis (Patriani, 2016).

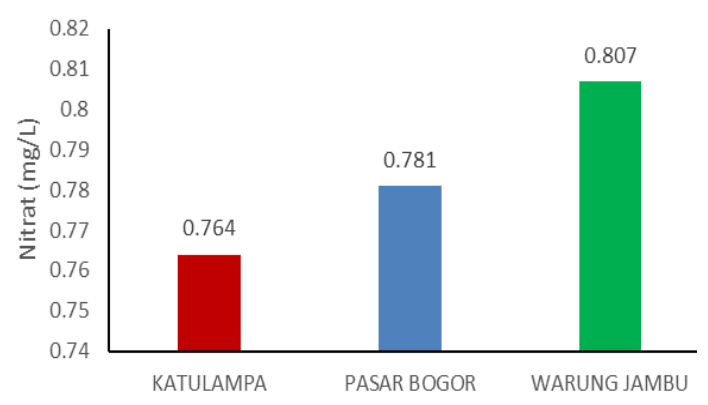

Gambar 6. Nilai Nitrat Rata-Rata 2017

\section{B. Dinamika Fosfat}

Peningkatan nilai fosfat disebabkan oleh meningkatnya berbagai masukan beban pencemaran yang diterima badan air, dan terakumulasi dari Katulampa hingga ke Warung Jambu. Beban pencemaran dapat bersumber dari limbah domestik, limbah 
pertanian, limbah industri, dan peternakan (Trofisa, 2011).

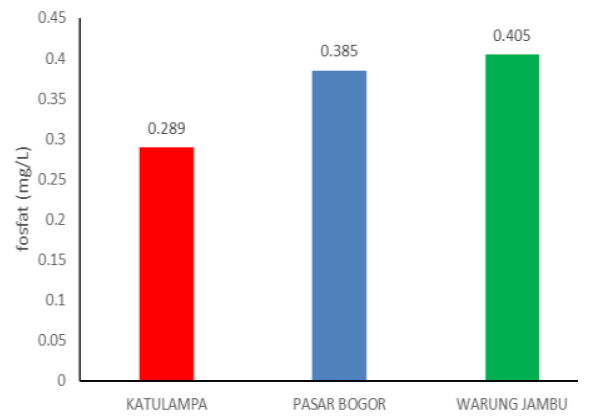

Gambar 7. Nilai Total Fosfat Rata-Rata 2017

Peningkatan nilai fosfat pada siang hari disebabkan karena tingginya aktivitas yang terjadi di siang hari yaitu penggunaan fosfat sebagai sumber utama zat hara yang digunakan oleh fitoplankton dalam proses metabolisme (fotosintesis). Keberadaan senyawa fosfat dalam air sangat berpengaruh terhadap keseimbangan ekosistem perairan. Bila kadar fosfat dalam perairan rendah maka pertumbuhan organisme atau tumbuhan air akan terhambat, sedangkan bila kadar fosfat dalam perairan tinggi maka pertumbuhan organisme atau tumbuhan air menjadi tidak terbatas, sehingga akan merusak kelestarian ekosistem air.

Nilai fosfat tahun 2017 mengalami fluktuasi peningkatan pada lokasi Katulampa sebesar 0,289 mg/L dan Pasar Bogor $0,385 \mathrm{mg} / \mathrm{L}$. Sedangkan, hasil penelitian Khoerussani (2014) menyatakan nilai fosfat pada lokasi Katulampa sebesar 0,214 mg/L dan Pasar Bogor 0,330 mg/L. Hal ini dapat disebabkan oleh tingginya difusi fosfat dari sedimen, dan meningkatnya pencemaran yang terjadi di sepanjang aliran sungai Ciliwung. Jika dibandingkan dengan data hasil uji BPLH Kota Bogor (2010-2013), maka nilai fosfat relatif berfluktuasi, dan melebihi batas kriteria baku mutu PP No. 82 tahun 2001 Kelas I dan II yaitu maksimal $0,2 \mathrm{mg} / \mathrm{L}$ (Badan Pengelolaan Lingkungan Hidup Daerah [BPLHD], 2014). Pada tahun 2013 nilai fosfat di Katulampa mengalami peningkatan, hal ini berhubungan dengan terjadinya peristiwa luapan sungai Ciliwung akibat curah hujan yang deras dalam beberapa hari, yang berakibat pada terjadinya bencana banjir di Jakarta. Peningkatan nilai fosfat tersebut diikuti oleh peningkatan konsentrasi parameter lain seperti tergambar pada grafik parameter penunjang sebelumnya.

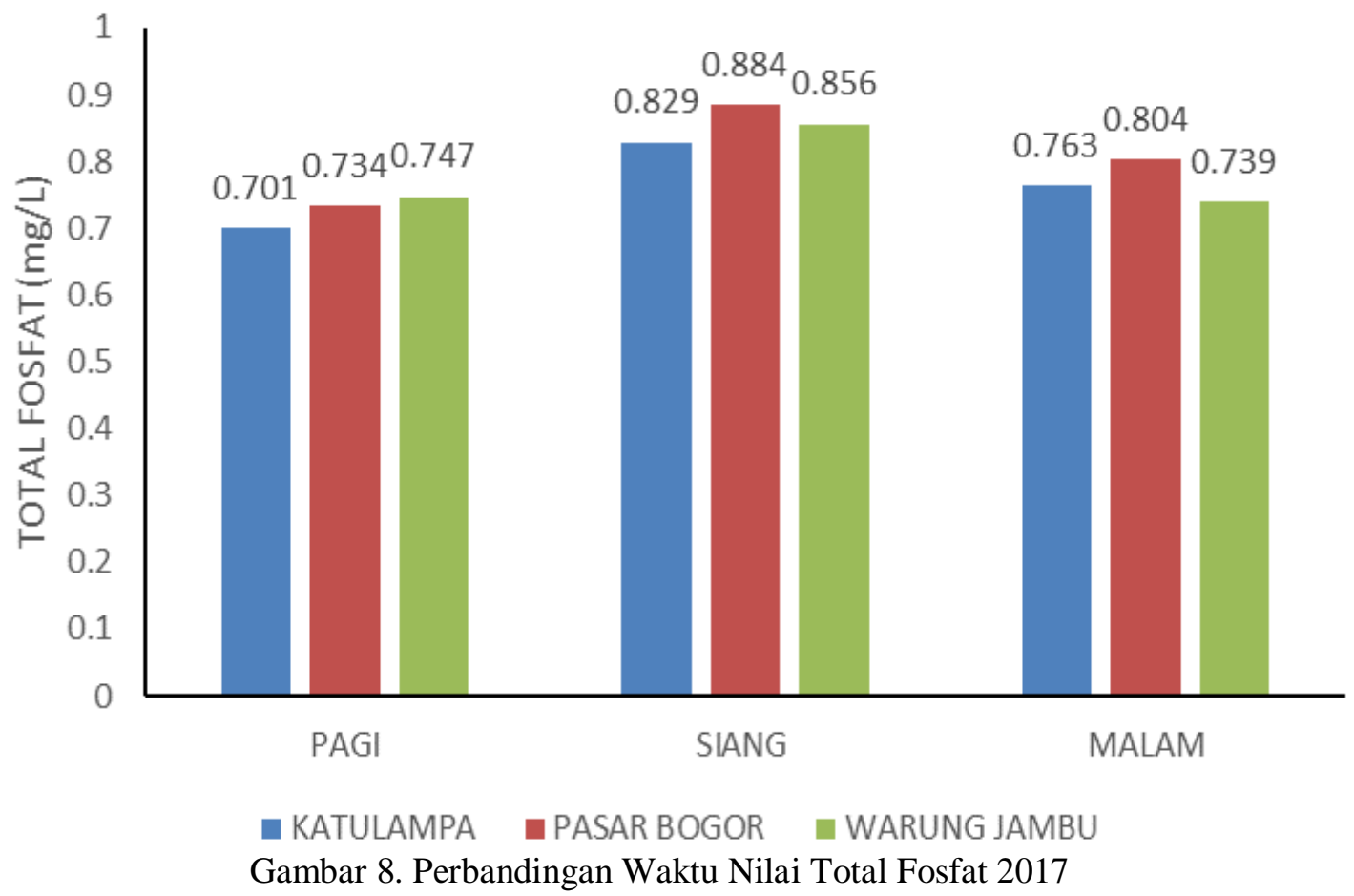

Jurnal Sains Natural Universitas Nusa Bangsa

Vol. 8, No.1, Januari 2018, 43-49 


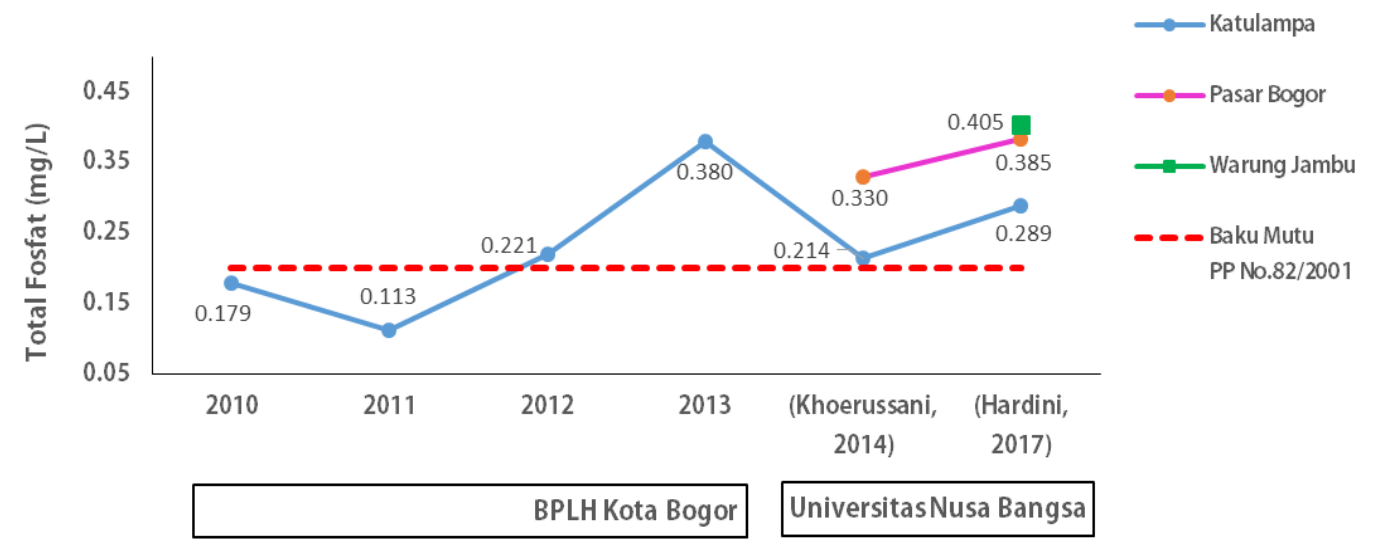

Gambar 9. Perbandingan Nilai Total Fosfat Tahun 2010-2017

Berdasarkan data hasil penelitian 2017, serta merujuk pada data penelitian Khoerussani (2014) dan data hasil uji BPLH Kota Bogor (BPLHD, 2014), maka dinamika peningkatan nilai fosfat pada DAS Ciliwung memiliki kesamaan hubungan terhadap peningkatan nilai suhu, TSS, BOD, nitrat, serta penurunan nilai $\mathrm{pH}$ dan DO. Menurut Effendi (2003) peningkatan suhu akan menyebabkan terjadinya peningkatan aktivitas enzim dan kecepatan proses metabolisme, peningkatan dekomposisi bahan organik, dan mengakibatkan penurunan konsentrasi oksigen terlarut dalam perairan.

Air sungai Ciliwung sepanjang titik Katulampa, Pasar Bogor, dan Warung Jambu tahun 2017 berada dalam tingkat sangat subur sekali dengan kadar total fosfat berkisar antara 0,289-0,405 mg/L (Gambar 9.), dan terindikasi berada dalam kondisi eutrofikasi (35-100 $\mu \mathrm{g} / \mathrm{L})$ dengan rentang nilai total fosfat sebesar 289-405 $\mu \mathrm{g} / \mathrm{L}$.

Menurut Tungka et al., (2016) keberadaan fosfat yang subur beserta konsentrasi nitrat yang melebihi ambang batas dapat memicu terjadinya proses pengkayaan nutrien perairan, dan berpotensi menyebabkan fenomena algae blooming. Potensi blooming algae dapat terjadi pada lokasi perairan yang tenang, bergerak lambat, tidak mengalir, serta terkena iklim hangat/cerah, biasanya terjadi pada kolam, danau, waduk, dan laut.

\section{KESIMPULAN}

Berdasarkan hasil penelitian, nilai fosfat DAS Ciliwung tahun 2017 mengalami peningkatan, dan melebihi baku mutu lingkungan PP No.82 tahun 2001 kelas I dan II. Konsentrasi total fosfat air sungai Ciliwung 2017 sebesar 0,405 mg/L.

\section{DAFTAR PUSTAKA}

APHA. (2005). Standard Method for Examination of Water and Wastewater. Author.

Badan Pengelolaan Lingkungan Hidup Daerah Jawa Barat. (2014). Data Pengujian Air Sungai. Diperoleh dari http://bplh.kotabogor.go.id/index.php Iragam_data\#

Effendi, H. (2003). Telaah Kualitas Air Bagi Pengelolaan Sumber Daya Alam dan Lingkungan Perairan. Yogyakarta: Kanisius.

Khoerussani, F. (2014). Analisis Sungai Ciliwung di Segmen Kota Bogor (Skripsi). Fakultas Matematika dan Ilmu Pengetahuan Alam, Universitas Nusa Bangsa, Bogor.

Kusuardini, A. (2011). Estimasi Konsentrasi Padatan Tersuspensi dan Klorofil-A dari Citra Modis Hubungannya dengan Marak Alga di Perairan Teluk Jakarta (Skripsi). 
Fakultas Perikanan dan Ilmu Kelautan, Institut Pertanian Bogor, Bogor.

Manurung, J. (2014). Kajian Beban Pencemaran dan Daya Tampung Beban Pencemaran Sungai Ciliwung Hulu Segmen Kabupaten Bogor (Skripsi). Fakultas Kehutanan, Institut Pertanian Bogor, Bogor.

Ndani, L. (2016). Penentuan Kadar Senyawa Fosfat Di Sungai Way Kahuripan Dan Way Kuala dengan Spektrofotometri Uv-Vis (Skripsi). Fakultas Matematika dan Ilmu Pengetahuan Alam, Institut Lampung, Lampung.

Patriani, R. (2016). Sebaran Nutrient dan Kematian Massal Ikan Pada Ledakan Alga (Algae Blooming) di Perairan Indonesia. Jakarta Utara: Pusat Penelitian dan Pengembangan Perikanan.
Priyono, A. (2011). Kajian Beban Pencemaran Limbah Usaha Kecil di Sungai Ciliwung Segmen Kota Bogor. Media Konservasi, 16(1), 3240.

Trofisa, D. (2011). Kajian Beban Pencemaran dan Daya Tampung Pencemaran Sungai Ciliwung di Segmen Kota Bogor (Skripsi). Fakultas Kehutanan, Institut Pertanian Bogor, Bogor.

Tungka, A.W., Haeruddin, dan Ain, C. (2016). Konsentrasi Nitrat dan Ortofosfat di Muara Sungai Banjir Kanal Barat dan Kaitannya dengan Kelimpahan Fitoplankton Harmful Alga Blooms (HABs). Indonesian Journal of Fisheries Science and Technology, 12(1), 40-46.

Wardhana, W. (1995). Dampak Pencemaran Lingkungan. Yogyakarta: ANDI Offset. 